УДК 34.096(07)

DOI https://doi.org/10.32837/npnuola.v26i0.662

\author{
I. В. Лукач, В. В. Поєдинок
}

\title{
ПРАКТИЧНІ НАПРЯМИ ВДОСКОНАЛЕННЯ ЮРИДИЧНОЇ ОСВІТИ В УКРАЇНІ
}

Постановка проблеми. Реформа юридичної освіти в Україні є необхідним складником утвердження верховенства права в усіх галузях і сферах суспільного життя, адже випускники юридичних закладів вищої освіти та факультетів (правничих шкіл) стають суддями, прокурорами, адвокатами, посідають провідні посади на державній службі тощо. Проблемою, яка потребує розв'язання в результаті реформи, є невідповідність змісту юридичної освіти та якості підготовки в правничих школах сучасним вимогам ринку праці та викликам, що стоять перед сучасним демократичним суспільством, глобальним тенденціям розвитку та завданням професійної діяльності правників у різних сферах діяльності [1].

Юридична (правнича) професія - це професія, що передбачає діяльність із застосування права. Відповідно, ключову роль в юридичній освіті повинні відігравати методики, максимально спрямовані на розвиток у здобувачів цієї освіти навичок практичного правозастосування. Тим часом традиційний для України, успадкований від радянських часів абстрактно-описовий спосіб викладання не дає студентам змоги підготуватися до практичної юридичної діяльності.

Стан дослідження. Окремі аспекти проблеми вдосконалення юридичної освіти піднімались у роботах Г. Едвардса, Б. Комарова, Р. Мельника, Б. Шлоера та інших. Першою комплексною працею, в якій було системно розглянуто різні аспекти вдосконалення юридичної освіти, стала Біла книга з реформування української юридичної освіти, видана за результатами міжнародної наукової конференції «Европеїзація української юридичної освіти: німецько-український досвід / Німецько-український правознавчий діалог» (2019) [2]. Проте в практичній площині стан вітчизняної юридичної освіти залишається далеким від бажаного.

Метою статті $€$ визначення проблем юридичної освіти в Україні та вироблення практичних напрямів їі вдосконалення.

Виклад основного матеріалу. Юридична освіта - це базис для розвитку громадянського суспільства та правової держави. Коли йдеться про юридичну освіту, то, як би це не звучало цинічно, йдеться перш за все не про студента, а про майбутній рівень фахової юридичної професії в країні. 
Адже завтра випускник юридичного факультету стане юристом, прокурором, адвокатом, суддею, державним службовцем або нотаріусом і буде вирішувати долю громадянина, держави та суспільства. 3 огляду на це в юридичної освіти є дві найбільш важливі мети.

По-перше, організація юридичної освіти важлива з огляду на формування цілісного світогляду правників, які покликані розбудовувати правову державу та громадянське суспільство, здійснювати захист прав людини. Від рівня їхньої правосвідомості залежить правова культура в державі, яка $€$ необхідним чинником у досяганні добробуту громадян, держави та суспільства. Без цього неможливо досягнути верховенства права в країні, адже саме випускники юридичних факультетів $є$ носіями не тільки спеціальних юридичних знань, але й правових цінностей. По-друге, юридична освіта має виховати грамотного, всебічно обізнаного фахівця в галузі права. Він має опанувати теорію права та вміти застосовувати право на практиці. При цьому теоретичний і практичний компоненти повинні нерозривно супроводжувати один одного.

Сьогодні Україна взяла курс на компетентнісний підхід в юридичній освіті. Парадигма компетентнісного підходу, як видно, алгоритмічна щодо всіх циклів і рівнів вищої юридичної освіти та дає можливість розвивати певну єдину політику у сфері освіти. Сам компетентнісний підхід загалом дає змогу передбачати результати освіти та полісистемно визначати стандарти якості освіти у вигляді компетентностей у певних ділянках вищої юридичної освіти та правничих професій, функції освіти, самовизначення і становлення індивідуальності в академічному середовищі, тобто він $є$, по суті, певною технологією моделювання розвитку освіти [3].

Реалізація цього підходу наштовхується на необхідність подолання наявних недоліків юридичної освіти, до яких автори Білої книги з реформування української юридичної освіти відносять такі: відсутність єдиних стандартів; недосконалість навчальних планів; недостатність практичного складника; потребу у висококваліфікованих викладацьких кадрах; недостатню орієнтацію на європейське законодавство та практику; використання застарілих (радянських) конструкцій і теорій як доктринального підгрунтя; потребу в збільшенні кількості студентів і викладачів, які володіли б європейськими мовами; потребу в оновленні способів викладення інформації на сторінках навчальної літератури; потребу в покращенні процедури оцінювання якості знань студентів і випускників [2, с. 18-36].

Розглянемо основні можливі напрями вдосконалення юридичної освіти в Україні.

1. Студенти мають засвоювати як теоретичні, так і практичні навички. Ця проблема притаманна не тільки українським університетам. У провідних американських правничих школах велася дискусія щодо дотримання такого балансу. До того ж абстрактно-узагальнюючий складник курсу не можна нівелювати, адже саме цих навичок може навчити університет, а не юридична фірма [4]. Проте теоретична частина проведення семінарського заняття не має бути репродукцією лекційного матеріалу: студенти мають готувати доповіді на основі прослуханого лекційного матеріалу, а для виступу має обиратися тема, яка в лекції глибоко не піднімалася. 
Наприклад, в лекції розглядалося питання «Припинення корпоративних прав» без деталізації питання виходу учасника з товариства з обмеженою відповідальністю. Останнє може бути темою для самостійного вивчення студентом, а також підготовки доповіді на основі прослуханого лекційного матеріалу, спеціальної літератури та узагальнення матеріалів практики.

2. Робота в групах є корисною для засвоєння як практичного, так і теоретичного матеріалу. Наприклад, група студентів може підготувати доповідь на обрану тему, супроводжуючи ї̈ презентацією. Ця форма роботи дає змогу структуровано розглядати питання, формувати практичні навички з фокусування на окремих напрямах проблеми, а також розвиває вміння застосовувати раніше набуті знання. Отже, студенти вчаться працювати в команді, знаходити компроміс і видавати єдине рішення на основі балансу інтересів групи. Іншим прикладом таких інтерактивних занять може бути вирішення мінізадач під час проведення семінарського заняття (не в межах домашньої роботи), коли студенти об'єднуються у групи та вчаться приймати та обгрунтовувати колективне рішення.

3. Проведення презентацій стало важливою частиною сучасної юридичної роботи на конференціях, семінарах і ділових зустрічах. Презентації активно застосовуються як у роботі юридичних департаментів, так і для підготовки проєктів. У навчальному процесі шляхом підготовки презентацій студенти поглиблюють свої знання та навчаються подавати складну інформацію коротко та водночас у достатньому для розкриття питання обсязі. Важливою частиною роботи є візуалізація матеріалу, якій необхідно приділити відповідну увагу. Презентація може у стислій і наглядній формі надати інформацію, яка б з голосу складно б сприймалася та / або потребувала б значного часу для записування студентами, наприклад: щодо джерел правового регулювання з певного питання, позицій судової практики, порівняння підходів законодавства різних країн. Найкращим заохоченням студентів до такого процесу має слугувати власний приклад викладача, який супроводжує свої лекції змістовними, добре структурованими й візуально привабливими презентаціями.

4. Матеріали судової практики можуть бути як окремим об’єктом вивчення на семінарах (наприклад, студентам можна дати завдання проаналізувати судову справу, яка справила особливий вплив на формування судової практики та зачіпає низку проблемних аспектів), так і складати частину інтерактивних занять. Особлива увага має приділятися судовій практиці під час вирішення юридичних задач (казусів), оскільки судові рішення є прикладами вирішення задач, які виникли в реальному житті.

5. Вивчення законодавства окремих зарубіжних країн і законодавства EC повинно стати частиною підготовки студентів до більшості семінарських занять. Це має значення з огляду на євроінтеграційні процеси в Україні, а також дасть можливість ознайомити студентів із зарубіжним досвідом розв'язання практичних проблем, що може статися їм у нагоді під час консультації зарубіжних клієнтів. Така необхідність підсилюється тим, що в Україні стрімко впроваджуються зарубіжні юридичні механізми, які донедавна не були відомі вітчизняному праву. Наприклад, тільки з початку 2017 р. було прийнято низку законів, якими було запроваджено 
такі нові для українського права юридичні конструкції, як корпоративний договір, опціонний продаж, squeeze-out та sell-out. За умови, що студенти готували чи слухали доповідь, що містила аналіз таких понять згідно із зарубіжним законодавством, вони будуть готові до їх імплементації у своїй практичній діяльності навіть без додаткового академічного вивчення відповідних механізмів. I тут знову має стати у нагоді власний приклад викладача - використання такого матеріалу під час проведення лекцій.

6. Важливим складником програми правничої освіти є формування первинних умінь і практичних навичок правозастосування. Більшість методичних розробок юридичного факультету Київського національного університету імені Тараса Шевченка історично традиційно передбачає вирішення юридичних задач. Проте бракує єдиної методики вирішення таких задач і вимог обов'язкового використання такої методики в навчальному процесі.

Безпрецедентним експериментом щодо втілення практичного компонента в юридичній освіті України стало впровадження німецької методики вирішення юридичних задач (казусів) на юридичному факультеті Київського національного університету імені Тараса Шевченка під керівництвом Центру німецького права [5]. Команда викладачів юридичного факультету, що представляють різні галузі права, проводила семінарські заняття на основі цієї методики. Позитивні ефекти згаданої методики полягають у тому, що вона:

- розвиває навички правозастосування (вміння орієнтуватися в системі права та структурі закону, вміння тлумачити норми права та встановлювати співвідношення конкуруючих норм, здатність застосовувати абстрактну норму права до конкретної життєвої ситуації тощо);

- полегшує вирішення задачі, оскільки є чіткі правила стосовно того, шо повинно зазначатися на кожному з кроків вирішення, і студентам не доводиться самотужки визначатися з тим, що і як треба писати;

- тренує навички практично орієнтованого юридичного письма, оскільки передбачає вирішення задач у стилі експертного висновку;

- є універсальною, тобто може бути використана під час вирішення будь-яких юридичних задач, що дає змогу розв'язувати на ії основі невідомі задачі, а в перспективі - реальні справи;

- актуалізує для студентів загальні питання культури логічного мислення, грамотного мовлення, дбайливого оформлення письмових робіт, управління часом (якісний експертний висновок неможливо підготувати в останню ніч або, тим більше, на перерві перед навчальним заняттям).

Як підсумок 3-річного експерименту викладачами юридичного факультету Київського національного університету імені Тараса Шевченка було видано навчальний посібник «Методика вирішення юридичних задач (казусів): теоретичні та практичні аспекти» [6], де пропонується комплексне висвітлення всіх значущих аспектів застосування методики вирішення казусів у вищій юридичній освіті - від теоретичних засад цієї методики до прикладних питань організації впровадження іï у навчальний процес.

7. Юридична освіта в Україні здійснюється в межах Болонського процесу. Відповідно до ч. 1 ст. 5 Закону України «Про вищу освіту» підготовка фахівців із вищою освітою здійснюється за відповідними освітніми чи нау- 
ковими програмами на таких рівнях вищої освіти: початковий рівень (короткий цикл) вищої освіти; перший (бакалаврський) рівень; другий (магістерський) рівень; третій (освітньо-науковий/освітньо-творчий) рівень; науковий рівень. Відповідно до Наказу МОН України від 23 січня 2004 р. № 48 було проведено педагогічний експеримент щодо впровадження кредитно-модульної системи організації навчального процесу у вищих навчальних закладах III-IV рівнів акредитації. Наказом МОН України від 13 жовтня 2016 р. № 1236 запроваджено зовнішнє незалежне оцінювання під час вступу до магістратури за спеціальністю 081 «Право» [8]. Отже, українська юридична освіта складається 3 освітніх ступенів «Бакалавр» і «Магістр».

До Верховної Ради України було внесено два законопроєкти № 7147 та 7147-1 «Про юридичну (правничу) освіту і загальний доступ до правничої професії» (обидва відкликано 29 серпня 2019 р.) [9; 10] (далі - законопроєкти про юридичну освіту). Перший законопроєкт визначав юридичну (правничу) освіту як вищу освіту за спеціальністю «Право», здобуття якої відбувається за наскрізною програмою в межах магістерського рівня вищої освіти. Другий же законопроєкт встановлював, що підготовка правника здійснюється в межах початкового (короткий цикл), першого (бакалаврського) та другого (магістерського) рівнів вищої освіти відповідно до стандартів юридичної (правничої) освіти. Отже, обидва законопроєкти були орієнтовані на Болонський процес, проте перший передбачав доступ до правничої професії лише магістрам, а другий - бакалаврам і магістрам.

В Україні щороку випускається багато юристів. Загальний затверджений обсяг на підготовку магістрів із права у 2019 р. - 2084 місця, з яких МОН - 1 750, МВС - 117, СБУ - 69, Міноборони - 31, Мінфін - 117. У 2018 р. загальна кількість місць на прийом у магістратуру становила 2342 місця, з яких МОН - 2 030, МВС - 125, СБУ - 22, Міноборони 21, Мінфін - 116, Мінкультури - 8, Мін'юст - 20. Враховуючи зазначене, на думку деяких державних службовців, залишається відкритим питання обгрунтування обсягів державного замовлення для підготовки юристів за спеціальностями 081 «Право» загалом і для закладів вищої освіти зі специфічними умовами навчання зокрема [11].

Однією з причин завеликої кількості закладів вищої освіти, що випускають юристів, є відсутність єдиного кваліфікаційного іспиту для отримання юридичної професії. Першою ластівкою на шляху до його запровадження став єдиний вступний іспит у магістратуру на правничі факультети. Наказом Міністерства освіти і науки України від 12 грудня 2018 р. № 1379 було затверджено стандарт вищої освіти за спеціальністю 081 «Право» для першого (бакалаврського) рівня вищої освіти [12]. Наразі розробляється стандарт вищої освіти за спеціальністю 081 «Право» для магістрів. Тільки після його прийняття можна буде ставити питання про єдиний кваліфікаційний іспит з огляду на те, що процес оцінювання має відповідати єдиним вимогам.

Потрібно вказати, що законопроєкти про юридичну освіту мали за основу впровадження єдиного державного кваліфікаційного іспиту. Наразі Урядом розробляється єдиний кваліфікаційний іспит, який не буде регулюватись законом, а, можливо, актами Міністерства освіти України. Наприклад, згідно з абз. 3 ч. 2 ст. 6 Закону України «Про вищу освіту» атеста- 
ція осіб на першому (бакалаврському) та/або другому (магістерському) рівнях вищої освіти може включати єдиний державний кваліфікаційний іспит, що проводиться за спеціальностями та в порядку, визначеними Кабінетом Міністрів України. Згідно з Постановою Кабінету Міністрів України від 17 липня 2019 р. № 684 «Про деякі питання атестації осіб, які здобувають ступінь магістра, у формі єдиного державного кваліфікаційного іспиту», відповідальними за організацію цього іспиту є Міністерство освіти та науки України, а також Міністерство юстиції України [13].

3 цих міркувань слід підтримати положення, що юридична освіта повинна відповідати єдиному стандарту, тобто в основу останнього має бути покладено універсальні вимоги до майбутнього юриста [14]; водночас необхідно забезпечити студенту можливість вільно обирати дисципліни за вибором (фактично так і відбувається його спеціалізація).

Висновки. Практичними напрямами вдосконалення юридичної освіти в межах проведення семінарів мають стати: 1) баланс лекційно-семінарських занять; 2) робота в групах (інтерактивні заняття); 3) підготовка презентацій; 4) вивчення матеріалів судової практики; 5) застосування законодавства зарубіжних країн; 6) вирішення практичних юридичних задач (казусів); 7) єдиний затверджений стандарт юридичної освіти з одночасним забезпеченням права студента вільно обирати частину дисциплін.

\section{Література}

1. Концепція розвитку юридичної освіти. МОН України, 2019. URL: https:/ / mon.gov.ua/ storage / app/media/vishcha-osvita / rozvitkuyuridichnoiosviti23052019.docx

2. Біла книга з реформування української юридичної освіти (за матеріалами міжнародної науково-практичної конференції «Європеїзація української юридичної освіти: німецько-український досвід» / Київ, 21 і 22 листопада 2014 р.). Упорядники: Р. Мельник, О. Шаблій, Б. Шлоєр. Київ : Корпорація «Науковий парк Київський університет імені Тараса Шевченка»; Панов, 2015.

3. Комаров В. Основоположні проблеми вищої юридичної освіти у парадигмі компетентнісного підходу. Юридична техніка: доктринальні основи та проблеми викладання : тези доп. та повідомл. учасників наук.-практ. конф., м. Харків, 30 вересня - 1 жовтня 2015 р. Харків, 2015. C. $7-12$.

4. Edwards H.D. The Growing Disjunction between Legal Education and the Legal Profession. Michigan Law Review. 1992-1993. № 34. P. 58-59

5. Центр німецького права. URL: http:/ / zdr.knu.ua/ua.

6. Шлоєр Б., Поєдинок В., Лукач І., Косілова О. Методика вирішення юридичних задач (казусів): теоретичні та практичні аспекти / за заг. редакцією Р. Мельника. Видавничий дім «Гельветика», 2020. 160 с.

7. Про вищу освіту : Закон України від 1 липня 2014 р. № 1556-VII. ВВР України. 2014. № 37-38. Ст. 2004.

8. Умови прийому на навчання до вищих навчальних закладів України в 2017 році : Наказ Міністерства освіти і науки України від 13 жовтня 2016 р. № 1236. URL: http:/ / mon.gov.ua/ usi-novivni / povidomlennya / 2016/10/13/umovi-prijomu-na-navchannya-do-vishhix-navchalnixzakladiv-ukrayini-v-2017-roczi.

9. Про юридичну (правничу) освіту і загальний доступ до правничої професії : проєкт Закону України від 28 вересня 2017 р. № 7147. URL: http://w1.c1.rada.gov.ua/pls/zweb2/ webproc4_1?pf3511=62613.

10. Про юридичну (правничу) освіту і загальний доступ до правничої професії : проєкт Закону України від 17 жовтня 2017 р. № 7147-1. URL: http:/ /w1.c1.rada.gov.ua/pls / zweb2/ webproc4_1?pf3511=62728.

11. Шемелинець I. Точка біфуркації: курс на продовження реформи юридичної освіти. URL: https: / / yur-gazeta.com/publications / practice/inshe/ tochka-bifurkaciyi-kurs-na-prodovzhennyareformi-yuridichnoyi-osviti.html. 
12. Стандарт вищої освіти за спеціальністю 081 «Право» для першого (бакалаврського) рівня вищої освіти : Наказ Міністерства освіти і науки України від 12 грудня 2018 p. № 1379. URL: https:/ / mon.gov.ua/storage/app/media/vishcha-osvita/zatverdzeni\% 20standarty/12/21/081-pravo-bakalavr.pdf.

13. Про деякі питання атестації осіб, які здобувають ступінь магістра, у формі єдиного державного кваліфікаційного іспиту : Постанова Кабінету Міністрів України від 17 липня 2019 р. № 684. Офіційний вісник України. 2019. № 62. Ст. 2152.

14. Опришко В. Особливості підготовки юристів у непрофільних вищих навчальних закладах України: сучасний стан і шляхи подальшого розвитку. Правове регулювання економіки. 2013. № 13. C. 6-27. C. 23.

\begin{abstract}
А н о т а ц і я
Лукач I. В., Поєдинок В. В. Практичні напрями вдосконалення юридичної освіти в Україні. - Стаття.

Реформа юридичної освіти в Україні є необхідним складником утвердження верховенства права в усіх галузях і сферах суспільного життя. Проблемою, яка потребує вирішення в результаті реформи, $є$ невідповідність змісту юридичної освіти та якості підготовки в правничих школах сучасним вимогам ринку праці та викликам, що стоять перед сучасним демократичним суспільством, глобальним тенденціям розвитку та завданням професійної діяльності правників у різних сферах діяльності.

Сьогодні Україна взяла курс на компетентнісний підхід в юридичній освіті. Парадигма компетентнісного підходу алгоритмічна щодо всіх циклів і рівнів вищої юридичної освіти та дає можливість розвивати певну єдину політику у сфері освіти. Реалізація цього підходу наштовхується на необхідність подолання наявних недоліків юридичної освіти, до яких належать, зокрема: відсутність єдиних стандартів; недосконалість навчальних планів; недостатність практичного складника; потреба у висококваліфікованих викладацьких кадpax; недостатня орієнтація на європейське законодавство та практику; використання застарілих (радянських) конструкції та теорій як доктринального підгрунтя; потреба в збільшенні кількості студентів і викладачів, які володіли б європейськими мовами; потреба в оновленні способів викладення інформації на сторінках навчальної літератури; потреба в покращенні процедури оцінювання якості знань студентів і випускників. Окремою проблемою є відсутність спеціального закону про юридичну освіту.

Авторами обгрунтовано низку практичних напрямів вдосконалення юридичної освіти: 1) засвоєння студентами як теоретичних знань, так і практичних навичок, що вимагає балансу лекційно-семінарських занять, 2) робота в групах (інтерактивні заняття); 3) підготовка презентацій; 4) вивчення матеріалів судової практики; 5) застосування законодавства зарубіжних країн; 6) вирішення юридичних задач (казусів); 7) юридична освіта повинна відповідати одному затвердженому стандарту, проте студент має право вільно обирати частину дисциплін.
\end{abstract}

Ключові слова: юридична освіта, компетентнісний підхід, практичний компонент освіти, вирішення юридичних задач, єдиний стандарт юридичної освіти.

\title{
S u $\mathrm{m} \mathrm{m}$ a r y
}

Lukach I. V., Poiedynok V. V. Practical approaches to the improvement of the legal education in Ukraine. - Article.

Reform of legal education in Ukraine is a necessary component of establishing the rule of law in all spheres and domains of public life. The problem that needs to be addressed as a result of the reform is the inconsistency of the content of legal education and the quality of training in law schools with the modern labor market requirements and challenges facing modern democratic society, global development trends and the task of professional legal activity in various fields.

Today, Ukraine has taken a course on a competency-based approach in legal education. The paradigm of the competency approach is algorithmic for all cycles and levels of higher legal education and makes it possible to develop a unified policy in the field of education. The implementation of this approach confronts with the need to overcome the existing shortcomings of legal education, which include, in particular: the lack of uniform standards; the imperfection of curricula; lack of practical component; the need for highly qualified teaching staff; insufficient 
focus on European legislation and practice; use of outdated (Soviet) constructions and theories as a doctrinal basis; the need to increase the number of students and teachers who speak European languages; the need to update the ways of presenting information on the pages of educational literature; the need to improve the procedure for assessing the quality of knowledge of students and graduates. A separate problem is the lack of a dedicated law on legal education.

The authors substantiate a number of practical ways of improving legal education in Ukraine: 1) teaching students both theoretical knowledge and practical skills, which requires a balance of lectures and seminars; 2) group work (interactive classes); 3) preparation of presentations; 4) case law studies; 5) application of foreign legislation; 6) practical solution of legal cases; 7 ) legal education must meet a uniform approved standard, but the students retain the right to freely choose some disciplines.

Key words: legal education, competence approach, practical component of education, solution of legal problems, uniform standard of legal education. 